\title{
A evolução da família numa perspectiva histórica, legislativa e educacional ${ }^{1}$
}

\author{
The evolution of the family in a historical, legislative and educational perspective
}

La evolución de la familia en una perspectiva histórica, legislativa y educacional

Maria do Rosario Pessoa Nascimento - Universidade Estadual do Piauí - UESPI | Professora Adjunta da UESPI |

Parnaíba | PI | Brasil. E-mail: rosariopessoa.adv@gmail.com

Resumo: Ao longo da História, a família passou por diversas transformações. Com base nas leituras de alguns teóricos do Direito e da Sociologia, a pesquisa visa apontar várias características que deram, a seu tempo, uma moldura distinta aos diferentes modelos de família. Da fase patriarcal até a contemporânea, diversas nuances deram a entender que a família está em desordem. O estudo comenta os Códigos de Hamurabi e de Manu destacando a indissolubilidade do casamento e a obediência ao pater familias. Ressalta o Direito de Família na legislação brasileira que contribuiu para reconhecer a união homoafetiva como entidade familiar. As mutações sociais sugerem uma família recomposta. A pesquisa mostra uma visão educativa no sentido de prevenir a formação dos filhos. A natureza qualitativa da pesquisa apoia-se em obras bibliográficas e artigos da internet. Conclui que a família influencia a educação dos(as) filhos(as) e fortalece a convivência entre parceiros(as).

Palavras-chave: Entidade familiar. Família tradicional. Família recomposta. União homoafetiva.

Abstract: Throughout history, the family has undergone several transformations. Based on the readings of some theorists of Law and Sociology, the research aims to point out several characteristics that gave, in time, a different frame to the different models of family. From the patriarchal to the contemporary phase, various nuances have suggested that the family is in disarray. The study comments on the Codes of Hamurabi and Manu highlighting the indissolubility of marriage and obedience to pater families. It underscores the Family Law in the Brazilian legislation that contributed to recognize the homoaffective union as a family entity. Social mutations suggest a recomposed family. The research shows an educational vision to prevent the formation of children. The qualitative nature of the research is based on bibliographical works and articles on the Internet. It concludes that the family influences the education of the children and strengthens the coexistence between partners.

Keywords: Family entity. Traditional family. Family recomposed. Homoafetive union.

Resumen: A lo largo de la Historia, la familia ha pasado por diversas transformaciones. Teniendo como base las lecturas de algunos teóricos del Derecho y de la Sociología la investigación tiene por objeto señalar varias características que han dado, a su tiempo, un marco distinto a los diferentes modelos de familia. De la fase patriarcal hasta la contemporánea, diversos matices han permitido entender que la familia está en desorden. El estudio comenta los Códigos de Hamurabi y de Manu destacando la indisolubilidad del matrimonio y la obediencia al pater familias. Resalta el Derecho de Familia en la legislación brasileña que ha contribuido para reconocer la unión homoafectiva como entidad familiar. Las mutaciones sociales sugieren una familia recompuesta. La investigación muestra una visión educativa en el sentido de prevenir la formación de los hijos. La naturaleza cualitativa de la investigación se apoya en obras bibliográficas y artículos de la Internet. Concluye que la familia influencia la educación de los(las) hijos(as) y fortalece la convivencia entre parejas.

Palabras clave: Entidad familiar. Familia tradicional. Familia recompuesta. Unión homoafectiva.

${ }^{1}$ Artigo reestruturado e ampliado após a apresentação no Congresso Internacional da Faculdades EST. Anais do Congresso Internacional da Faculdades EST. São Leopoldo: EST, v. 2, 2014.

- Recebido em 25 de julho de 2016 • Aprovado em 29 de abril 2019 • e-ISSN: 2177-5796

DOI: https://doi.org/10.22483/2177-5796.2019v21n1p221-241

Copyright @ 2019. Conteúdo de acesso aberto, distribuído sob os termos da Licença Internaonal da CreativeCommons - CC BY-NC-SA Atribuição Não Comercial (https://br.creativecommons.org/licencas/) - Permite distribuição e reprodução, desde que atribuam os devido créditos à publicação, ao autor(es) e que licenciem as novas criações sob termos idênticos. 


\section{Introdução}

A evolução histórica mostra que, por muito tempo, a sociedade formatou a família como uma comunidade presa a regramentos que lhe foram impostos ao longo dos tempos, como preceituado pelo sistema jurídico, moldado no Código Civil Brasileiro, de 1916 - Lei no 3.071 (BRASIL, 1916), vigente por quase um século. Diante da nova realidade social, a legislação avançou, editando a lei do divórcio que veio regulamentar condutas que o Código estabelecia como padrões de uma família nuclear da sociedade do século XIX.

A evolução legislativa, a partir da Emenda Constitucional 09/1977 (BRASIL, 1977a) ${ }^{2}$ e a consequente Lei $\mathrm{n}^{\circ} 6.515$ de 1977 (BRASIL, 1977b) ${ }^{3}$ - Lei do Divórcio, bem como a Lei $\mathrm{n}^{\circ}$ 10.406 - Código Civil, de 2002 (BRASIL, 2002), que revogou o Código Civil de 1916 - Lei ${ }^{\circ}$ 3.071 (BRASIL, 1916), registra que novos direitos foram reconhecidos na relação familiar, fazendo prevalecer o princípio da diginidade da pessoa humana, como princípio fundamental da República Federativa no Brasil, conforme artigo $1^{\text {}}$, III da Constituição Federal) (BRASIL, 1988). Com isso, algumas normas às quais as pessoas não mais respeitavam, ante a realidade social, foram alteradas, alcançando diretamente o núcleo familiar, quando a legislação possibilitou a Separação judicial, reconhecendo o fim de algumas obrigações, como se dissolvido estivesse o casamento 1977 (BRASIL, 1977b) ${ }^{4}$.

\footnotetext{
${ }^{2}$ Emenda Constitucional 09/1977.

Art. $1^{\circ}$. O $\S 1^{\circ}$ do artigo 175 da Constituição Federal passa a vigorar com a seguinte redação:

"Art. 175 -

$\S 1^{\circ}$ - O casamento somente poderá ser dissolvido, nos casos expressos em lei, desde que haja prévia separação judicial por mais de três anos".

Art. $2^{\circ}$ A separação, de que trata o $\S 1^{\circ}$ do artigo 175 da Constituição, poderá ser de fato, devidamente comprovada em Juízo, e pelo prazo de cinco anos, se for anterior à data desta emenda.

${ }^{3}$ Lei n ${ }^{\circ} 6.515 / 1977$ - Art. $2^{\circ}$. A Sociedade Conjugal termina:

I -

III - pela separação judicial;

IV - pelo divórcio.

Parágrafo único - O casamento válido somente se dissolve pela morte de um dos cônjuges ou pelo divórcio

${ }^{4}$ Lei $n^{\circ} 6.515 / 1977$ - Art. $3^{\circ}$. A separação judicial põe termo aos deveres de coabitação, fidelidade recíproca e ao regime matrimonial de bens, como se o casamento fosse dissolvido.
} 
A Constituição Federal de 1988 (BRASIL, 1988), recepcionando a evolução histórica e legislativa, preceitua no artigo 226, em seus parágrafos, novas concepções de família ${ }^{5}$. Reconheceu a união estável, como entidade familiar ${ }^{6}$. Instaurou a igualdade entre homem e mulher ${ }^{7}$, ampliou o conceito de família e protegeu seus integrantes, imputando-lhes deveres e garantindo-lhes direitos. Além disso, a Constituição abriu a possibilidade de reconhecimento das relações homoafetivas como pretensas famílias a merecerem a proteção jurídica, inibindo, assim, a discriminação contra pessoas do mesmo sexo nas suas relações consensuais, como preceituado no artigo 226, parágrafo $4^{\circ}$ (BRASIL, 1988). Com isso, quis o legislador constituinte respeitar o pincípio da dignidade humana, pois, nesse processo evolutivo, como preceito fundamental, a norma constitucional, artigo 226, parágrafo $7^{\circ}$ (BRASIL, 1988), deu liberdade ao casal de planejar sua prole, em nome da paternidade responsável ${ }^{8}$.

Por fim, a Magna Carta, revogando as disposições do Código Civil de $1916^{9}$ que entendia como filhos ilegítimos os nascidos de relações espúrias, reconheceu que "os filhos, havidos ou não da relação do casamento, ou por adoção, terão os mesmos direitos e qualificações, proibidas quaisquer designações discriminatórias relativas à filiação” (BRASIL, 1988, p. 117), como o fez no seu artigo 227 , parágrafo $6^{\circ}$.

Dessa forma, sendo a família uma comunidade, cujas relações sociais variam no tempo, poderá agregar novos costumes, apresentar distintas formas de convivência e conquistar outros direitos. Para a análise dessas mudanças, basta observar o modus vivendi da família patriarcal e compará-la às atuais formas de família na modernidade. Não haverá dúvida de que poucas características da família nuclear seriam identificadas na atualidade.

\footnotetext{
5 Art. 226, $\S 4^{\text {o }}$. Entende-se também como entidade familiar a comunidade formada por qualquer dos pais e seus descendentes.

${ }^{6}$ Art. 226. $\S 3^{\circ}$. Para efeito de proteção do Estado, é reconhecida a união estável entre homem e mulher como entidade familiar, devendo a lei facilitar sua conversão em casamento.

7 Art. 226. $\S 5^{\circ}$. Os direitos e deveres referentes à sociedade conjugal são exercidos igualmente pelo homem e pela mulher.

${ }^{8}$ Art. 226, $\S 7^{\circ}$ - Fundado nos princípios da dignidade da pessoa humana e da paternidade responsável, o planejamento familiar é livre decisão do casal, competindo ao Estado propiciar recursos educacionais e científicos para o exercício desse direito, vedada qualquer forma coercitiva por parte de instituições oficiais ou privadas.

${ }^{9}$ Art. 227. $\S 6^{\circ}$. Os filhos havidos ou não da relação do casamento, ou por adoção, terão os mesmos direitos e qualificações, proibidas quaisquer designações discriminatórias. Relativas à filiação.
}

Quaestio, Sorocaba, SP, v. 21, n. 1, p. 221-241, jan./abr. 2019. 


\section{Aportes conceituais}

Família é uma palavra de origem latina (familia). Segundo o Dicionário Aurélio, significa "Conjunto de todos os parentes de uma pessoa, e, principalmente, dos que moram com ela; conjunto formado pelos pais e pelos filhos; conjunto formado por duas pessoas ligadas pelo casamento e eventuais descentes: conjunto de pessoas que têm ancestral em comum; conjunto de pessoas que vivem na mesma casa" (FERREIRA, 2017).

Para Danda Prado (2011, p. 16), a família não é um fenômeno natural: "ela é uma instituição social que varia ao longo da História e até apresenta formas e finalidades diversas numa mesma época e lugar, conforme o grupo social que esteja sendo observado". Conforme a autora, a família, enquanto instituição social, apresenta aspectos distintos: positivos, como núcleo afetivo de apoio e solidariedade, e negativos, que surgem quando a família impõe normas "por meio de leis, usos e costumes, que implicam formas e finalidades rígidas. Torna-se, muitas vezes, elemento de coação social, geradora de conflitos e ambiguidades” (PRADO, 2011, p. 17).

Vanessa Faco e Lígia Melchiori (2009, p. 121) destacam que "a família representa o espaço de socialização, de busca coletiva de estratégias de sobrevivência, local para o exercício da cidadania, possibilidade para o desenvolvimento individual e grupal de seus membros". Ressaltam as autoras que esse espaço de socialização independe dos arranjos apresentados ou das novas estruturas que vêm se formando; possui dinâmica própria e corresponde ao desenvolvimento de seu ciclo vital sendo afetado pelas políticas econômicas e sociais.

Ressaltam essas autoras, com base em Dessen e Braz (2005 apud FACO; MELCHIORI, 2009, p. 121), que:

Ela é um dos principais contextos de socialização dos indivíduos e, portanto, possui um papel fundamental para a compreensão do desenvolvimento humano, que por sua vez é um processo em constante transformação, sendo multideterminado por fatores do próprio indivíduo e por aspectos mais amplos do contexto social no qual estão inseridos.

Faco e Melchiori (2009, p. 122) não esqueceram de lembrar, ainda: “a família é um complexo sistema de organização, com crenças, valores e práticas desenvolvidas diretamente ligadas às transformações sociais buscando, tanto quanto possível, a melhor adaptação para a sobrevivência de seus membros e da instituição como um todo". Além disso, enfatizam que “o sistema familiar muda à medida que a sociedade muda, e todos os seus membros podem ser afetados por pressões interna e externa, fazendo que ela se modifique com a finalidade de 
assegurar a continuidade e o crescimento psicossocial de seus membros" (FACO; MELCHIORI, 2009, p. 122).

Por acréscimo, aduz Paulo Nader (2008, p. 23), com relação à sociabilidade humana: "a própria constituição física do ser humano revela que ele foi programado para conviver e se completar com outro ser de sua espécie. A prole, decorrência natural da união, passa a atuar como fator de organização e estabilidade de núcleo familiar".

Nesse contexto, vê-se que a família não é uma organização estática. À medida que a sociedade muda, a família tende a se modificar. E, se a sociedade muda, o Direito também se modifica para normatizar os direitos provenientes dessas transformações sociais. Assim, todos os membros do sistema familiar podem ser afetados por mudanças culturais, sociais, políticas e econômicas que ocorrem com o passar do tempo, obrigando a sociedade a se reorganizar para garantir a nova ordem familiar e seu respectivo desenvolvimento.

\section{Origem e evolução}

As diferentes formas de família têm-se apresentado, desde os primórdios, variando no tempo e no espaço, conforme a cultura vigente. A evolução, a diversidade e o desenvolvimento em torno da família acompanham sua respectiva trajetória. Nesse percurso, a família ultrapassa a muralha da relação privada para alcançar a esfera pública. Assim, ocorreu em tempos idos, quando ter uma família, saber conduzi-la era um requisito indispensável para habilitar-se à vida pública (ARENDT, 2014).

Nesse sentido, a esfera privada compreendia a casa, a família e aquilo que é próprio ao homem: serviçais, patrimônio etc. Presumia um reino da violência em que só o chefe da família exercia o poder arbitrário sobre os membros que se submetiam ao seu mando (mulher, filhos, escravos). As pessoas viviam juntas e submissas, para satisfazerem suas necessidades e carências biológicas: alimentação, alojamento, segurança contra inimigos. A necessidade era, pois, a motivação da atividade no lar. Como destaca Hannah Arendt (2014, p. 35), "historicamente é muito provável que o surgimento da cidade-Estado e do domínio público tenha ocorrido à custa do domínio privado da família e do lar".

Nesse contexto, o chefe da família alimentava a todos os integrantes e dava-lhes segurança face às ameaças internas, no caso das revoltas dos escravos, ou, externamente, na 
iminência de destruição de uma casa ou família. O poder do chefe da família era incontestável. Nenhum outro poder lhe era superior. Na esfera privada o homem era impossibilitado da mais importante capacidade humana - a ação política - caso não fosse bem sucedido como chefe da família. Portanto, "sem possuir uma casa, um homem não podia participar dos assuntos públicos porque não tinha nele algum que fosse propriamente seu” (ARENDT, 2014, p. 35).

Conforme Hanah Arendt (2014), havia um traço distintivo da esfera do lar: o fato de que no âmbito doméstico os homens viviam juntos por serem compelidos a tal circunstância em razão das suas necessidades e carências. Esclarece a filósofa alemã, que a mantença individual devia ser a tarefa do homem, enquanto a sobrevivência da espécie, a tarefa da mulher. Isso era tido como óbvio. "Ambas as funções naturais, o trabalho do homem para fornecer o sustento e o trabalho da mulher no parto, eram sujeitas às mesmas premências da vida" (p. 36). Conclui a autora que "a comunidade natural nascia da necessidade, e a necessidade governava todas as atividades realizadas nela" (p. 36).

Arendt (2014, p. 38) propõe a existência de uma distinção entre a polis e o lar, em razão do fato de a polis "somente conhecer os iguais, ao passo que o lar era o centro da mais severa desigualdade. Ser livre significava ao mesmo tempo não estar sujeito às necessidades da vida nem ao comando de outro e também não comandar". Por tais razões, o homem só era considerado plenamente humano se ultrapassasse o domínio instintivo e natural da vida privada. Essa limitação de poder impunha-lhe uma circunstância de escravidão. Por isso, ambicionava a vida pública, a vida boa, da liberdade. Portanto, a condição para alcançar a vida pública era ter sido um bom exemplo como administrador da família (ARENDT, 2014).

Ao longo da história da humanidade, novas formas de família vêm-se apresentando na sociedade contemporânea. Sua trajetória contou com inúmeras modificações decorrentes da própria evolução social. Assim, na realidade brasileira, até que se chegue às atuais concepções sobre família, será necessário um breve relato para descrever, ainda que sucintamente, essa evolução.

O Código Civil - Lei nº 3.071/1916 (BRASIL, 1916) -, vigente por quase um século, trazia plena visão discriminatória em relação à família. Segundo Farias e Rosenvald (2012, p. 49), “este Código mostrava a imagem de família matrimonializada, patriarcal, hierarquizada, heteroparental, biológica, como unidade de produção e reprodução e caráter institucional, tal como se conhecia, ao final do século XIX". O casamento era indissolúvel; a expressão "até que a 
morte os separe" (FARIAS; ROSENVALD, 2012, p. 40), como lembra o autor, inspirava a bênção sacerdotal no casamento religioso. Significava dizer: Deus uniu, o homem não separa.

Sendo a indissolubilidade a regra, quando o casamento não prosperava, buscava-se a solução do conflito matrimonial através do desquite, que possibilitava a ruptura na comunhão das vidas dos cônjuges, ocorrendo a separação de corpos, mas não lhes dava o direito de romper o vínculo jurídico. Assim, o Código Civil Brasileiro de 1916, no artigo 233, preceituava ser o marido o chefe da sociedade conjugal, cuja função era exercida com a colaboração da mulher, no interesse comum do casal e dos filhos (BRASIL, 1916).

Quanto à prole, o mesmo Código, a reger as relações familiares, discriminava os filhos havidos fora do casamento que eram condenados pela sociedade, ao serem taxados de bastardos por serem ilegítimos, porque eram provenientes de uma relação espúria. A família, como se uma empresa fosse, tinha um chefe (o marido) e os respectivos subalternos (mulher, filhos e agregados). Tudo muito semelhante à família patriarcal, em confronto com as novas relações familiares, como afirma Gonçalves (2005, p. 16):

O Código Civil de 1916 e as leis posteriores, vigentes no século passado, regulavam a família constituída unicamente pelo casamento, de modelo patriarcal e hierarquizada, ao passo que o moderno enfoque pelo qual é identificada tem indicado novos elementos que compõem as relações familiares, destacando-se os vínculos afetivos que norteiam a sua formação.

Contudo, a evolução social e familiar, diante das alterações legislativas que foram surgindo, tornara-se inevitável. Revogando o Código Civil Brasileiro de 1916, a Lei n 4.121/62 - Estatuto da Mulher Casada - retirava da competência do marido a administração dos bens da mulher, ao declarar sua plena capacidade, garantindo-lhe a propriedade dos bens adquiridos com o fruto do seu trabalho ${ }^{10}$.

Posteriormente, a Emenda Constitucional no 09/1977 - Lei nº 6.515/1977, “acabou com a indissolubilidade do casamento, eliminando a ideia de família como instituição sacralizada", como enfatiza Berenice Dias (2007, p. 30). A própria Constituição Federal de 1988 no art. 226, Par. $5^{\circ}$, trouxe inúmeras garantias aos membros da família: repartiu as responsabilidades entre o

${ }^{10}$ Art. 240 do Codigo Civil Brasileiro/1916. A mulher, com o casamento, assume a condição de companheira, consorte e colaboradora do marido nos encargos de família, cumprindo-lhe velar pela direção material e moral desta. Redação dada pela Lei nº 6.515, de 26 de dezembro 1977. 
homem e a mulher e denominou de filhos(as) (BRASIL, 1988) ${ }^{11}$, quem nascesse de relações, mesmo fora do casamento, descaracterizando qualquer forma discriminatória que atentem contra o saudável desenvolvimento da criança e do adolescente. (BRASIL, 1988).

A Lei no 10.406/2002 - Código Civil atual, ao ser publicado (BRASIL, 2002), já chegou ultrapassado, pois se encontrava em descompasso com o ordenamento jurídico. Como diz Berenice Dias (2007, p. 32), "talvez o grande ganho tenha sido excluir expressões e conceitos que causavam grande mal-estar e não mais podiam conviver com a nova estrutura jurídica e a moderna conformação da sociedade".

Não obstante a evolução jurídica, a realidade social nem sempre acompanha a lei. As transformações sociais, ocorridas nas últimas décadas, alcançaram diretamente o núcleo familiar, dando origem a novas concepções de família, que não mais se equiparam àquelas vivenciadas pela tradicional família patriarcal.

\section{Da família patriarcal e tradicional}

Na Idade Antiga, o sistema familiar, regido por lei patriarcal constituía-se a partir do casamento monogâmico, embora fosse admitido o concubinato, nas devidas proporções, pois uma concubina nunca teria os mesmos direitos da esposa. O casamento legítimo somente era válido, se realizado por um contrato. Diante da possibilidade de casamentos entre camadas sociais distintas, o Código de Hamurabi (TELA HEBRAICA, 2012) ${ }^{12}$ (mais antigo que o de Manu, em pelo menos 1500 anos), como uma coletânea de normas, regulava a sucessão prevendo a herança dos filhos nascidos deste relacionamento e admitia o divórcio, pois ao marido era permitido repudiar a mulher nos casos do não cumprimento de seus deveres de esposa e dona-de-casa.

O Código de Manu tinha uma visão extremamente discriminatória com relação à família. Dispunha sobre a indissolubilidade do casamento, embora houvesse divergência, já que, à época, era permitido o divórcio. Preceituava a distinção entre seus membros: a chefia da família cabia ao marido; esposa e filhos (legítimos) ficavam em posição inferior. Discriminava pessoas unidas fora dos laços matrimoniais; os filhos nascidos fora do casamento eram considerados ilegítimos.

11 Art. 227. $\S 6^{\circ}$. Os filhos havidos ou não da relação do casamento, ou por adoção, terão os mesmos direitos e qualificações, proibidas quaisquer designações discriminatórias. Relativas à filiação.

12 O Código de leis de uma sociedade organizada sofre influência direta da cultura e de seus costumes. As leis mosaicas refletem o pensamento oriental no mundo antigo sobre o casamento, o divórcio e outros assuntos perpetuados pelo Código de Hamurabi. 
A vontade da família era a vontade do homem, que se transformava na vontade da entidade familiar (LOUZADA, 2013).

Segundo Louzada (2013), a palavra família, no Direito Romano, era indistintamente aplicada tanto às coisas, como às pessoas. Quando se falava de patrimônio, este compreendia o conjunto de coisas ou bens da família. A família compreendia o pai (pater familias), chefe da família, que revestido da autoridade de sacerdote (potifex), assumia também a função de juiz (domesticus magistratus). Além do pai, a família era composta pelos filhos (patrea potestas), pela mulher (manus) e os escravos (dominica potestas). Todos como membros da família eram submetidos à autoridade do chefe, cabeça (caput) da entidade familiar. Em se tratando das pessoas, a família pressupunha parentesco, não necessariamente consanguíneo. Significava dizer que todas as pessoas que estivessem sob o poder de um mesmo pater familias a este pertenciam.

Vê-se, assim, que a família patriarcal inspirou o modelo de família tradicional, cujo centro da sociedade não é o indivíduo, mas a entidade familiar monogâmica, parental. A tradicional família romana, abrigada pelo cristianismo medieval, justificava o domínio das terras pelos patriarcas e pelos senhores feudais.

Segundo Arendt (2014, p. 34), “o que chamamos de 'sociedade’ é o conjunto de famílias economicamente organizadas de modo a constituírem um fac-símile de uma única família sobrehumana, e sua forma de organização é denominada "nação"”. Assim, a sociedade humana, como uma sociedade de famílias, os indivíduos, a sociedade política e o cidadão eram de pouco valor. Na sociedade patriarcal não havia lugar para o indivíduo sem família, pois se tratava de um ser infeliz, pobre coitado, incapaz de constituir família. Espelhada na origem de Roma, a família tradicional, pelo menos na civilização ocidental, tinha por base a família patriarcal e senhorial.

A família tradicional originou-se da combinação rígida da prática sexual monogâmica de um homem com uma mulher na qualidade de pai e mãe, esta sob a condição de gerar filhos e cuidar dos afazeres da casa. Sob o poder, sustento e proteção do pai, os filhos podiam herdar o patrimônio da família, como forma de assegurar que as terras dos romanos não saíssem de suas mãos, mas perpetuassem em seu poder, através da descendência destes. Não se concebia família sem um pai e uma mãe (ARENDT, 2014).

A lei exigia a fidelidade no casamento. Em geral, a pena de morte aplicava-se ao adultério. "Para os romanos, o casamento era um ato consensual de contínua convivência. Era um fato e não um estado de direito" (LOUZADA, 2013, p. 2). 
Com efeito, na Idade Média, considerando a hegemonia da Igreja, o Direito Canônico passou a ter importância relevante na sociedade. Com isso, os assuntos referentes a casamento, divórcio, legitimidade dos filhos passavam a ser de competência da Igreja. Nesse contexto, o casamento perde o caráter contratual para ser considerado um sacramento. Para a Igreja, o sexo dentro do casamento tinha uma só finalidade: a procriação. E as regras que lhe fossem contrárias eram também contra Deus.

\section{A Família no Direito Brasileiro}

No Brasil, o Código Civil é a principal lei que rege a instituição familiar. Contém normas referentes ao matrimônio, ao parentesco, aos filhos, à herança etc. Leis ordinárias vão surgindo, visando acompanhar a evolução social. Assim, a Lei no 3.071, de 1916, "primeiro Código Civil Brasileiro, inspirado no Direito Romano, no Direito Canônico e no Código Civil Napoleônico, recepcionado por todas as Constituições que o sucederam, trazia características da família patriarcal, regida pelo casamento monogâmico" (TEPEDINO, 2004, p. 2).

Por esse Código Civil, atualmente revogado, a família tinha por base o matrimônio regido pelo Direito canônico, sendo o casamento religioso, o único conhecido. Até 1960, as preocupações do Estado estavam voltadas para problemas como a epidemia e demografia. Em 1962, a evolução social provocou expressivas mudanças na legislação nacional. A lei 4.121/62 conhecida como Estatuto da Mulher Casada - prevendo sua plena capacidade, concedendo-lhe a competência da administração dos bens, como frutos do seu trabalho, constitui um considerável avanço legislativo (BRASIL, 1962).

Com a edição da lei $\mathrm{n}^{\mathrm{o}}$ 6.515/77 - Lei do divórcio - ao preceituar que "a sociedade Conjugal termina pelo divórcio" no Art. $2^{\circ}$, IV (BRASIL, 1977b) ${ }^{13}$, surgiram novos paradigmas: pessoas, antes unidas pelo casamento indissolúvel, passaram a formar distintos grupos familiares. Desde então, a família vem se apresentando com outro discurso: números de divórcio; procriação

\footnotetext{
${ }^{13}$ Lei $n^{\circ} 6.515 / 1977$ - Art. $2^{\circ}$. A Sociedade Conjugal termina:

I -

II -

III - pela separação judicial;

IV - pelo divórcio.

Parágrafo único - O casamento válido somente se dissolve pela morte de um dos cônjuges ou pelo divórcio.
} 
fora do casamento; baixa da fecundidade; descriminalização do aborto, adoção por casais homoafetivos.

O novo diploma legal, como aduz Berenice Dias (2007, p. 30), "acabou com a indissolubilidade do casamento, eliminando a ideia de família como instituição sacralizada”. Contudo, o sistema jurídico e a realidade social nem sempre caminham juntos. Assim, as transformações sociais, nas últimas décadas, alcançaram a família nuclear, dando origem a novas concepções de família, distintas da família patriarcal.

Em 1988, a Constituição, com relação à família, reconheceu mudanças sociais que perpassam valores presentes na realidade brasileira, como destaca Oliveira (2002, p. 91): "não foi a partir dela que toda a mudança ocorreu. Constitucionalizaram valores que já estavam impregnados no seio da sociedade", porque, antes mesmo que a lei reconhecesse direitos de família, pessoas conviviam sob o mesmo teto e até geravam filhos, independentemente da denominação que a sociedade atribuísse a essa união. A novidade foi a Carta Política contemplar e abrigar a evolução fática, vivida antes desse reconhecimento.

Segundo Danda Prado (2002), a Constituição, com o ânimo protetor da família, “criou uma série de figuras jurídicas, equiparando algumas situações existentes às civilmente previstas, como união estável, onde a simples convivência garante direitos e estabelece direitos entre companheiros" (p. 88). Além disso, visando proteger a instituição familiar, a Magna Carta equiparou os filhos adotados aos legítimos, para efeito de herança (PRADO, 2002).

Em 2002, depois de o Projeto de Lei transitar por 25 anos nas mãos dos parlamentares, foi editada a nova lei para reger a sociedade quanto aos direitos civis. Sob n ${ }^{\circ}$. 10.406/2002 (BRASIL, 2002), a lei foi proclamada como Código Civil Brasileiro. Fruto da evolução social, o atual Código veio consagrar o que já estava estabelecido pela Constituição, propondo inúmeras alterações legislativas direcionadas à família. Estas mudanças trouxeram um novo conceito de família, manifestando-se em diferentes nuances.

As formas como a família atualmente se manifesta sofreram diversas modificações ao longo da História. A família, como instituição, é uma coletividade humana subordinada a autoridades e condutas sociais. Conforme Venosa (2007), “considera-se família toda união onde seus membros, afetivos ou consanguíneos, tenham o intuito de constituir família, com ou sem filhos, bastando que estes membros sejam unidos por um laço de afeto" (p. 7). 
Segundo a Constituição Federal de 1988, no artigo 226: "A família, base da sociedade, tem especial proteção do Estado” (BRASIL, 1988, p. 116). Vê-se, assim, que a família, como uma célula humana com o preceito de total proteção do Estado, equivale a partículas que formam a sociedade. Nesses moldes, o sistema jurídico estabeleceu regramentos que alcançaram diretamente a célula familiar, regulamentando a possibilidade de diversas concepções de família, instaurando a igualdade entre homem e mulher, ampliando o conceito de família e protegendo todos os seus integrantes. Nessa diversificação, alguns estudiosos, como Elisabeth Roudinesco (2013) a descreveram como uma aparente família em desordem.

\section{A Família em desordem}

Do início da modernidade à fase contemporânea, importantes estudos têm-se realizado sobre a temática família, como o da psicanalista Elizabeth Roudinesco (2013), que analisa questões instigantes desde as origens da família patriarcal até as novas entidades caracterizadas como família. Segundo a autora, a alteração dos costumes e a instabilidade econômica, que se instauram na sociedade moderna, suscitam um "desejo de família, como uma expressão provocadora, sintoma relacionado à família ocidental, que pareceria pervertida na sua função social, levando a uma repercussão em nível sociopolítico e democrático, incorrendo no risco de uma decomposição com efeitos negativos” (ROUDINESCO, 2013, p. 11).

Roudinesco (2013) aborda a temática sobre vários aspectos. Ao tratar do fenômeno familiar, analisando os fatores sociológico, histórico ou psicanítico, privilegia "a verticalidade de filiações, gerações, continuidades, transmissão de saberes” (p. 67); pela visão antropológica, a autora elege a horizontalidade estrutural, comparando alianças onde surge cada família como fruto de duas outras famílias, anteriormente, constituídas. A autora enfatiza a capacidade que tem a família de assumir este conflito e de promover nova ordem simbólica, sob a demanda de que: "a família do futuro precisa ser reinventada" (p. 67).

Conforme essa historiadora, a evolução da família é marcada por três longos períodos do século XVI ao século XVIII: 1) a família tradicional, submetida à autoridade patriarcal; 2) família moderna, sob a divisão dos poderes entre o Estado e os pais; 3) família contemporânea ou pósmoderna, com rupturas e recomposições conjugais. 
Roudinesco (2013) reporta-se à família em desordem, onde uma das questões abordadas fala do 'filho culpado', que na concepção de Freud vai "inventar a família edipiana" [...] "Hamlet, portanto, é Édipo mascarado ou Édipo recalcado". Essa concepção tem o cerne da questão no desejo sexual e na culpa filial edipiana. Por outro lado, a análise da questão, 'o patriarca mutilado', na concepção da autora, pauta-se na invenção de Freud, que "esteve na origem de uma nova concepção da família ocidental, capaz de lidar, à luz de grandes mitos, não apenas com o declínio da soberania do pai, mas também com o princípio de uma emancipação da subjetividade" (ROUDINESCO, 2013, p. 67).

Quando se refere ao “poder das mães”, Roudinesco (2013, p. 149) assinala a passagem do feminino-materno para a posição feminina de "progressivamente dominar os processos de procriação", incluindo um poder com acusações, temores sobre a fertilidade e masculinização feminina e feminilização dos homens. Ressalta que "todas essas metamorfoses não faziam senão traduzir as angústias de um mundo abalado por suas próprias inovações” (p. 149), donde surgiu a contestação à família edipiana. Para a autora, a família recomposta contemporânea é "frágil, neurótica, consciente de sua desordem [...], mas persiste na busca de equilíbrio, donde provém também o seu vigor" (p. 149).

Outras questões são discutidas por Roudinesco (2013, p. 152) como a "mudança do filhoobjeto, para o filho-sujeito e a homologação da autoridade parental dividida com a 'maternalização' da família nuclear do século XX'. Acrescenta que a dominação/igualdade entre homem e mulher, citando Simone de Beauvoir, separa a feminilidade/maternidade até o ponto de admitir-se, na atualidade, a mulher/família monoparental, e não mais filho bastardo.

Das questões apresentadas por Roudinesco (2013, p. 152), ao que parece, nada mais resta da família tradicional, "Existe, sim, um descompasso entre a regulamentação vigente a dar proteção à família brasileira e a seus novos modelos. Com efeito, diversos arranjos familiares surgem, na atualidade, sem qualquer proteção”. Nessas circunstâncias, a Jurisprudência, suprindo a lacuna normativa, tende a garantir os mesmos direitos concedidos à família regulamentada.

A Constituição Federal (BRASIL, 1988, p. 116) preceitua no art. 226. § $3^{\circ}$ que "para efeito da proteção do Estado, é reconhecida a união estável entre o homem e a mulher, como entidade familiar, devendo a lei facilitar sua conversão em casamento". Com isso, a Magna Carta, recepcionando a legislação ordinária em vigor, limita-se a reconhecer como entidade familiar, digna da proteção estatal, o casamento e a união estável formada entre um homem e uma mulher. 
Com efeito, a lei não acompanhou os constantes avanços da sociedade contemporânea. Uma das principais características dessa nova família é a formação de um conceito, não mais fechado, formatado, mas um novo conceito, ao contrário daquele dos meados do século XX. Sua grande capacidade é assimilar mudanças, transformações, para que seu caminhar se mostre cada vez mais dinâmico e aberto, de modo a respeitar a dignidade da pessoa humana, nas diversas relações sociais. No Brasil, a sociedade caminhou para um modelo de família, inserindo mudanças radicais, propondo o novo modo de ver e de pensar a família.

Outro questionamento aborda Roudinesco (2013, p. 154): a 'família do futuro', aponta que a principal característica dessa família é a procriação humana de forma diferenciada da relação sexual. Trata-se do processo de fertilização homóloga, "passando a admitir que os filhos sejam fecundados fora do corpo da mãe biológica, em um útero de empréstimo, que abrigará o óvulo fertilizado; o sêmen que não é mais do pai biológico, mas sim, de um doador, de origem genética desconhecida, goza da proteção ao seu anonimato” (p. 154).

Nesse contexto, a forte discussão repousa no fato de que, na fertilização heteróloga, utiliza-se material genético (óvulo e sêmen) de terceiros, necessitando do consentimento do marido, que permitirá realizar o processo de inseminação FIV (Fecundação In Vitro) em sua esposa. A grande diferença é que a família nuclear é constituída por laços consanguíneos, como prevê a Lei; enquanto que na nova família prevalece a vontade deliberada dos membros.

Na linha de entendimento de Roudinesco (2013), a vontade neste novo núcleo está centrada na vontade de cada um dos seus membros, por laços da simples convivência de pessoas estranhas ao seio familiar consanguíneo, porque visa à realização plena de cada um dos seus integrantes. Vê-se, assim, que as relações familiares passaram por significativas mudanças, e hoje tais relações estão fundamentadas em razão da dignidade de cada participante, como pessoas humanas que são.

\section{A família recomposta}

Desde a Constituição Federal brasileira de 1934, o Princípio da Indissolubilidade do casamento previa que "A família, constituída pelo casamento indissolúvel, está sob a proteção especial do Estado" (BRASIL, 1934). Esse princípio foi repetido nas Constituição de 1937, 1946 e 1967. Quando da proclamação da Constituição Federal, em 1988, o casamento ainda sofria dos 
resquícios da indissolubilidade. A possibilidade de divórcio ficava sob a condição prévia de separação judicial por mais de um ano, nos casos expressos em lei, ou comprovada separação de fato por mais de dois anos. Mas a evolução social veio reforçar a proposta da Lei do divórcio em 1977.

As mudanças ocorridas provocaram, mais ainda, a legislação com a aprovação da Emenda Constitucional $\mathrm{n}^{\mathrm{o}}$ 66, de 2010 (BRASIL, 2010) ${ }^{14}$, considerada a nova lei do divórcio, proporcionou a dissolução da sociedade conjugal através do divórcio direto. Assim, o parágrafo $6^{\circ}$ do art. 226 da Constituição Federal, então, passa a vigorar, a partir de 13 de julho de 2010, da seguinte forma: "O casamento civil pode ser dissolvido pelo divórcio" (BRASIL, 2010). Com isso, o Direito passa a reconhecer as mutações sociais, no que diz respeito às relações afetivas, reduzindo o tempo de espera durante os relacionamentos conjugais que, de fato, não mais se mantinham.

Dessa forma, independentemente da possibilidade do divórcio, a família vem assumindo diferentes formas, momento em que os estudiosos têm denominado as novas entidades familiares como família recomposta, o que remete a uma situação anterior, considerando que só se recompõe aquilo que um dia foi decomposto, dividido e até desfeito. Assim, entendendo a relação familiar, proveniente de uma situação antecessora, com forma diversa, é necessário conhecer outros membros que se agregam ao grupo familiar com lugares definidos e denominações próprias.

Quando do uso dos termos "padrasto" e "madrasta" em uma nova relação familiar, essas figuras tendem a substituir o que antes se denominava, respectivamente, pai e mãe. Segundo Cutsem (2001, p. 89), “utilizaremos estes termos no sentido restrito, ou seja, quando existe novo casamento; caso contrário, falaremos em namorada do pai ou namorado da mãe. Ao utilizarmos o termo parceiro, estaremos a falar tanto do cônjuge casado como do(a) namorado(a)".

Pelas denominações adotadas por Cutsem (2001), presume-se que o autor fala de família formada de membros héteros. No caso de tratar-se de famílias homoafetivas, questões de gênero mudam os termos, podendo-se dizer o namorado do pai ou a namorada mãe, De igual forma, pode-se dizer a parceira da mãe ou o parceiro do pai. Evita-se o termo concubino(a), de cunho jurídico, para não denotar situação pejorativa, o que pode afetar a pessoa por questões

\footnotetext{
${ }^{14}$ A EC n n 66/2010 exclui a parte final do dispositivo constitucional, desaparecendo toda e qualquer restrição para a concessão do divórcio, que cabe ser concedido sem prévia separação e sem a exigência de prazos.
} 
psicológicas, pois "parece-nos atualmente manchado por um juízo moral pouco respeitador da escolha amorosa das famílias" (CUTSEM, 2001, p. 89).

$\mathrm{Na}$ família recomposta, as crianças têm consciência dos novos relacionamentos e não havendo vínculo jurídico entre a criança e o/a padrasto/madrasta, não será muito fácil falar de namorado(a) de qualquer um(a) dos(as) genitores(as). Para Cutsem (2001, p. 90), "no plano dos direitos e deveres no que respeita às crianças, a opção do casamento ou da coabitação é, deste modo, pouco importante para a segunda família”. Quanto aos cônjuges, tais circunstâncias não geram insegurança quanto a possíveis direitos que vierem a ser reivindicados, já que as relações se solidificam e para o Direito produzem efeitos, independentemente de estarem sob o mesmo ou diferentes tetos, ou ainda de viverem uma relação plenamente legalizada.

Nessa conjuntura, é possível que uma nova dificuldade venha se insurgir, caso inexista o vínculo entre a criança e o novo membro da família: a impossibilidade de exercer sua autoridade sobre as crianças do primeiro casamento, não assumindo, assim qualquer responsabilidade sobre as mesmas. Não tomando parte na educação das crianças, isso não significa que será uma pessoa ausente, pois sua atitude "pode exercer uma influência considerável sobre essas crianças e até, por vezes, assumir a parte mais importante de uma função parental” (CUTSEM, 2001, p. 90). Essa situação é tanto mais verídica quando o(a) genitor(a) biológico(a) não prescindir de sua presença na fase educacional das crianças.

Acredita-se que o autor não está enfatizando a presença física. Atualmente, o pai ou a mãe, em razão de seus compromissos de trabalho, têm permanecido fora de casa para exercerem suas atividades laborais em outros locais distantes do lar. Contudo, é importante ressaltar que o acompanhamento, mesmo à distância, em nada deve prejudicar a educação dos(as) filhos(as), mesmo porque os meios de comunicação e a inovação produzida pela tecnologia podem, plenamente, suprir essa ausência física, que logo é recompensada no momento do reencontro.

Outro obstáculo pode vir a ser enfrentado, se houver uma nova separação, pois um relacionamento significativo com as crianças do segundo casamento poderá ser interrompido e o(a) padrasto/madrasta perderá o contato com as crianças. Nesse caso, caberia indagar: como as crianças poderão compreender a questão familiar? Terão elas uma noção do que seja uma família? As novas situações constituiriam um desafio para outra família ou uma incerteza para as crianças? E diante de diferentes relacionamentos, poderia a educação das crianças ficar em uma situação vulnerável. 
Quando se trata das relações na família original, não existem muitas dificuldades quanto à partilha da autoridade parental, uma vez que "a existência da primeira família é regulamentada pelo direito. A dissolução obedece a regras bastante precisas sobre o divórcio, separação e o estatuto da criança" (CUTSEM, 2001, p. 90). A própria Constituição Federal de 1988, no seu artigo 205, preceitua que "a educação, direito de todos e dever do Estado e da família, será promovida e incentivada com a colaboração da sociedade, visando ao pleno desenvolvimento da pessoa, seu preparo para o exercício da cidadania e sua qualificação para o trabalho" (BRASIL, 2017, p. 149).

Com efeito, esse dispositivo constitucional corresponde a uma norma programática, e, como um programa educacional, sua eficácia fica sujeita à aplicabilidade da Lei. Contudo, embora a Lei ${ }^{\circ}$ 9.394/96 - das Diretrizes e Bases (BRASIL, 1996) ${ }^{15}$ - preveja normas atinentes à educação, não há garantia de que a educação seja prestada. Muitos fatores contribuem para ausência ou a evasão na escola: recursos orçamentários, número de vagas insuficiente na escola pública, condições financeiras da família, interesses particulares dos diferentes pais etc.

Diante desses prováveis impasses, Cutsem (2001) esclarece que o desenlace da primeira família é protegido pela legislação, que prevê a situação da guarda, partilhada ou não, direito de visitas, bem como a questão dos alimentos, sejam filhos biológicos ou por adoção, o que não acontece na família recomposta. Acrescenta o autor que, na família recomposta, o elo de parentesco se perfaz pelo laço afetivo; não é, portanto, biológico ou jurídico. Essa situação pode acarretar outros impasses, pois "se já é difícil prever o futuro desta família, mais difícil ainda se torna organizar as consequências de uma eventual ruptura, no que diz respeito à autoridade parental, obrigações alimentares, etc" (CUTSEM, 2001, p. 91).

Assegura Cutsem (2001, p. 92) que as crianças, "por vezes, respeitam mais os valores enunciados pelos pais biológicos, invocando uma maior legitimidade destes; outras vezes, pelo contrário, dão razão ao parceiro, tomada de posição que legitima sua função parental”. Nesse trilhar, muitas vezes, inseguro, existem situações, umas menos e outras mais complexas, no momento em que o(a) pai/mãe tem que tomar decisões para justificar sua posição não somente em relação ao(a) parceiro(a), mas ainda em relação aos filhos, que se adaptam e tentam tirar proveito deste processo.

\footnotetext{
${ }^{15}$ Lei n ${ }^{\circ}$ 9.394/1996. Art. $1^{\circ}$. A educação abrange os processos formativos que se desenvolvem na vida familiar, na convivência humana, no trabalho, nas instituições de ensino e pesquisa, nos movimentos sociais e organizações da sociedade civil e nas manifestações culturais.
} 
A experiência familiar tem mostrado que sempre as crianças ousam tirar proveito das situações entre os(as) pais/mães, desde que as decisões lhes sejam favoráveis. Por outro lado, nas divergências entre o casal ou parceiros(as) um dos pares colocam o(a) filho(a) contra ou favor do outro(a). Não raro, isto ocorre em situações conflituosas que configuram a alienação parental. Essas circunstâncias, não raro, se agravam e terminam buscando solução no Poder Judiciário, culminando numa situação cada vez mais delicada para qualquer um dos membros do núcleo familiar, sobretudo para as crianças.

Situação muito corriqueira é colocada por Cutsem (2001, p. 99), ao afirmar que

Nas famílias nucleares, todos sabem como funciona a autoridade parental. Eis alguns exemplos: ou é partilhada entre os dois progenitores, ou a mãe resolve os problemas diários e o pai intervém nas decisões importantes, ou o pai detém a autoridade e a mãe refere-se a ele em relação a todos os assuntos, ou a mãe resolve todos os problemas e o pai deposita toda confiança nela.

Diante dessas consistentes bases teóricas, pode-se entender que na convivência, muitas vezes, fragilizada por vários fatores, os(as) filhos(as) buscam sua identidade. Essa situação, se considerada em ambiente harmonioso, tende a contribuir para a educação do indivíduo, que pode amadurecer mais cedo. Contudo, se os genitores vivem em lares constantemente conflituosos, a relação pode acarretar inúmeros problemas, não raro, de natureza psíquica, de caráter identitário.

\section{Considerações finais}

Diante de todo esse manancial teórico, é possível entender que a família, ao longo da História passou por diversas mudanças, Da austeridade da família patriarcal, regida pelo direito romano, assume diversas formas inspiradas no direito comparado, na atualidade. De um contrato, passa a ser um sacramento e volta a ser regida por leis que, no caso brasileiro, não deixa de ser também um contrato, mas que poderá está dotado de relações de afetos.

A família, aparentemente organizada, estruturada com elementos héteros, alcança diferentes modelos. De outra forma, poderá constituir-se por pessoas do mesmo sexo. Nessa metamorfose constante, até se considera que a família está em desordem. A evolução social, fortalecida pela legislação, pode contribuir para que os(as) descendentes, não necessariamente oriundos de laços consanguíneos, possam ter nascido de uma relação plenamente consensual. 
Assim, tendo a família chegado a novas situações, diante de desencontros ocorridos nas relações anteriores, possa ela se recompor, buscando uma relação harmoniosa e visando à boa educação dos(as) filhos(as) e à saúde social de todos os seus membros.

No entanto, independentemente da forma como se apresenta, a família deve ser considerada uma célula que compõe e organiza a sociedade, contribuindo, assim, para o desenvolvimento individual ou grupal dos seus membros. Ela é uma instituição social, variável conforme lugares e culturas distintas, mas, ainda assim, a existência da família deve ser a esperança para uma harmônica convivência social.

Nessas inconsistências, os(as) filhos(as) buscam em qual dos(as) pais/mães poderão identificar a autoridade parental, ou com quem poderão contar como apoio nos momentos de indecisões. Frequentemente na adolescência, ficam perdidos(as) sem saber onde está um ombro amigo para chorarem suas mágoas, quem poderá esclarecer suas dúvidas, onde encontrarão um porto seguro a lhes proporcionar segurança, ou alguém para contarem sobre seus sonhos.

Com efeito, sob o ângulo educacional, o grande desafio está na capacidade de, não só os(as) filhos(as) enfrentarem esse turbilhão de mudanças nos diversos modelos de família na contemporaneidade, mas também os(as) pais/mães, padrastos e madrastas se reinventarem para conviverem em harmonia diante de novas relações sociais de afeto e companheirismo.

Não se pode negar que é na família que os(as) filhos chegam cedinho, engatinham, crescem, andam e caem. Mas o mais importante é que, após caírem, levantam-se mais fortalecidos e prontos para trilharem seus próprios caminhos, porque têm consciência de que tiveram uma família.

\section{Referências}

ARENDT, Hannah. A condição humana. 11. ed. Rio de Janeiro: Forense, 2014.

BRASIL. Constituição da República dos Estados Unidos do Brasil de 1934. Legislação informatizada - Constituição de 1934 - Publicação original. Brasília: Câmara dos Deputados. Disponível em: https://www2.camara.leg.br/legin/fed/consti/1930-1939/constituicao-1934-16julho-1934-365196-publicacaooriginal-1-pl.html. Acesso em: 23 jul. 2017.

BRASIL. Constituição da República Federativa do Brasil 1988. 54. ed. São Paulo: Saraiva, 2017. 
BRASIL. Constituição 1988. Emenda Constitucional no 66, de 13 de julho de 2010. Dá nova redação ao $\S 6^{\circ}$ do Art. 226 da Constituição Federal, que dispõe sobre a dissolubilidade do casamento civil pelo divórcio, suprimindo o requisito de prévia separação judicial por mais de 1 (um) ano ou de comprovada separação de fato por mais de 2 (dois) anos. Disponível em: http://www.planalto.gov.br/ccivil_03/constituicao/emendas/emc/emc66.htm. Acesso em: 23 jul. 2017.

BRASIL. Lei n⿳ 10.406, de 10 de jan. de 2002. Institui o Código Civil Brasileiro. D.O.U de 11 jan. 2002. Disponível em: http://www.normaslegais.com.br/legislacao/lei10406.htm. Acesso em: 23 jul. 2017.

BRASIL. Lei n ${ }^{\circ} 3.071$, de $1^{\circ}$ de janeiro de 1916. Código Civil dos Estados Unidos do Brasil. Diário Oficial da União - Seção 1 - 5/1/1916, Página 133 (Publicação Original). Origem: Poder Legislativo. Disponível em: http://www2.camara.leg.br/legin/fed/lei/1910-1919/lei-3071-1janeiro-1916-397989-norma-pl.html. Acesso em: 28 jan. 2019.

BRASIL. Lei no 9.394, de 26 de dezembro de 1996. Estabelece as diretrizes e bases da educação nacional. Disponível em: http://www.planalto.gov.br/ccivil_03/leis/L9394.htm. Acesso em: 23 jul. 2017.

BRASIL. Emenda Constitucional nº 09, de 28 de junho de 1977a. Dá nova redação ao $§ 1^{\circ}$ do artigo 175 da Constituição Federal. Disponível em: https://www2.camara.leg.br/legin/fed/emecon/1970-1979/emendaconstitucional-9-28-junho1977-366981-publicacaooriginal-1-pl.html. Acesso em: 23 jul. 2017.

BRASIL. Lei no 6.515, de 26 de dezembro de 1977b. Regula os casos de dissolução da sociedade conjugal e do casamento, seus efeitos e respectivos processos, e dá outras providências. Disponível em: https://presrepublica.jusbrasil.com.br/legislacao/103444/antigalei-do-divorcio-e-da-separacao-judicial-lei-6515-77. Acesso em: 23 jul. 2017.

BRASIL. Lei $n^{\circ}$ 4.121, de 27 de agosto de 1962. Dispõem sobre a situação jurídicada mulher casada. Disponívem em: http://www.planalto.gov.br/ccivil_03/leis/1950-1969/L4121.htm. Acesso em: 13 jul. 2017.

CUTSEM, Chantal V. A família recomposta: entre o desafio e a incerteza. Lisboa, Portugal: Editions Éres, 2001.

DIAS, Maria Berenice. Manual de direito das famílias. 4. ed. São Paulo: Revista dos Tribunais, 2007.

FACO, Vanessa M. Gibran; MELCHIORI, Lígia Ebner. Conceitos de família: adolescentes de zonas rural e urbana. In: VALLE, T. G. M. (org.). Aprendizagem e desenvolvimento humano: avaliações e intervenções [online]. São Paulo: Cultura Acadêmica, 2009. p. 121-135. Disponível em: http://books.scielo.org/id/krj5p/pdf/valle-9788598605999.pdf. Acesso em: 20 jul. 2017. 
FARIAS, Cristiano Chaves de; ROSENVALD, Nelson. Curso de direito civil: direito de famílias. 4. ed. Salvador: Jus Podvium, 2012.

FERREIRA, Aurélio Buarque de Holanda. Dicionário Aurélio de Português Online. Disponível em: https://dicionariodoaurelio.com/familia. Acesso em: 23 jul. 2017.

GONÇALVES, Carlos Roberto. Direito civil brasileiro: direito de família. São Paulo: Saraiva, 2005. v. 6.

LOUZADA, Ana Maria Gonçalves. A evolução do conceito de família. Revista eletrônica de doutrina e jurisprudência, Brasília, p. 1-14. Disponível em:

https://www.amagis.org.br/images/Artigos/Evolucao_do_conceito_de_familia.pdf. Acesso em: 15 out. 2013.

NADER, Paulo. Introdução ao estudo de direito. Rio de Janeiro: Forense, 2008.

OLIVEIRA, J. Sebastião. Fundamentos constitucionais do direito de família. São Paulo: Revistas dos Tribunais, 2002.

PRADO, Danda. O que é família. 2. ed. São Paulo: Brasiliense, 2011.

ROUDINESCO, Elisabeth. A família em desordem. Rio de Janeiro: Jorge Zahar, 2013.

TELA HEBRAICA. Disponível em: http://telahebraica.blogspot.com.br/2012/06/o-divorcio-nomundo-antigo-o-codigo-de.html . Acesso em: 23 jul. 2017.

TEPEDINO, Gustavo. Temas do direito civil. 3. ed. Rio de Janeiro: Renovar, 2004.

VENOSA, S. Sílvio. Introdução ao estudo do direito. 2. ed. São Paulo: Atlas, 2007. 